\title{
Analisis Pengaruh Variabel Ekonomi Makro terhadap Indeks Saham Syariah Indonesia (ISSI) periode 2016 - 2019
}

\author{
Emet Chotib ${ }^{1}$, Nurul Huda ${ }^{2}$ \\ ${ }^{1}$ Magister Manajemen, Sekolah Pascasarjana, Universitas YARSI, Jakarta \\ 2 Magister Manajemen, Sekolah Pascasarjana, Universitas YARSI, Jakarta
}

\section{Article}

Information

\section{History of article:}

Received: 08-04-2019

Approved: 23-05-2019

Published: 30-06-2019

Keywords: Exchange Rates, SBIS, BI Rate, Money Supply, ISSI

\begin{abstract}
The study aims to determine the effect of Exchange Rates on the Movement of the Indonesian Islamic Stock Index (ISSI); the effect of Sharia Bank Indonesia Certificates (SBIS) on the Movement of the Indonesian Sharia Stock Index (ISSI); the effect of Bank Indonesia Certificates (SBI) on the Movement of the Indonesian Sharia Stock Index (ISSI), and the effect of the Offer of Money (M2) on the Movement of the Indonesian Sharia Stock Index (ISSI). The data analysis method used was VAR Analysis using Eviews 5.0 software. Data is obtained during the period from January 2016 to January 2019. The results of the study show that the Exchange Rate influences the movement of the Indonesian Syariah Stock Index (ISSI) and encourages a decline in the Indonesian Syariah Stock Index (ISSI). Bank Indonesia Syariah Certificate (SBIS) influences the movement of the Indonesian Syariah Stock Index (ISSI) and encourages a decline in the Indonesian Syariah Stock Index (ISSI). The Bank Indonesia Rate (BI) influences the movement of the Indonesian Sharia Stock Index (ISSI) and encourages an increase in the Indonesian Islamic Stock Index (ISSI). Offering Money (M2) / Amount of Money Supply (JUB) affects the movement of the Indonesian Sharia Stock Index (ISSI) and encourages an increase in the Indonesian Syariah Stock Index (ISSI).
\end{abstract}

\begin{abstract}
Abstrak
Penelitian bertujuan untuk mengetahui pengaruh Nilai Tukar terhadap Pergerakan Indeks Saham Syariah Indonesia (ISSI); pengaruh Sertifikat Bank Indonesia Syariah (SBIS) terhadap Pergerakan Indeks Saham Syariah Indonesia (ISSI); pengaruh Sertifikat Bank Indonesia (SBI) terhadap Pergerakan Indeks Saham Syariah Indonesia (ISSI), dan pengaruh Penawaran Uang (M2) terhadap Pergerakan Indeks Saham Syariah Indonesia (ISSI). Metode analisa data yang digunakan adalah Analisa VAR dengan menggunakan software Eviews 5.0. Data diperoleh selama periode Januari 2016 sampai Januari 2019. Hasil penelitian menunjukkan bahwa Nilai Tukar berpengaruh terhadap pergerakan Indeks Saham Syariah Indonesia (ISSI) dan mendorong menurunnya Indeks Saham Syariah Indonesia (ISSI). Sertifikat Bank Indonesia Syariah (SBIS) berpengaruh terhadap pergerakan Indeks Saham Syariah Indonesia (ISSI) dan mendorong menurunnya Indeks Saham Syariah Indonesia (ISSI). Bank Indonesia Rate (BI) berpengaruh terhadap pergerakan Indeks Saham Syariah Indonesia (ISSI) dan mendorong meningkatnya Indeks Saham Syariah Indonesia (ISSI). Penawaran Uang (M2)/Jumlah Uang Beredar (JUB) berpengaruh terhadap pergerakan Indeks Saham Syariah Indonesia (ISSI) dan mendorong meningkatnya Indeks Saham Syariah Indonesia (ISSI).
\end{abstract}




\section{PENDAHULUAN}

Industri keuangan syariah setiap tahun terus mengalami perkembangan. Saat ini yang berkembang bukan hanya industri perbankan syariah, namun juga industri bukan bank syariah seperti pasar modal syariah. Produk keuangan di pasar modal syariah juga beragam. Selain produk sukuk, obligasi maupun reksadana dan produk saham syariah memiliki peminat yang banyak. Saham syariah dapat menjadi solusi bagi para investor khususnya investor Muslim sebelumnya hanya tersedia saham konvensional yang dipenuhi oleh tindakan spekulasi, riba maupun kecurangan seperti penggorengan saham.

Penilaian sebuah saham yang diterbitkan merupakan saham syariah atau bukan berdasarkan indeks yang berlaku di Indonesia. Di Indonesia indeks yang digunakan dalam penilaian saham syariah adalah indeks saham syariah indonesia (ISSI). Indeks Saham Syariah (ISSI) adalah keseluruhan saham syariah yang terdaftar pada Bursa Efek Indonesia (BEI). Seluruh saham syariah yang terdaftar pada ISSI juga terdaftar dalam Daftar Efek Syariah (DES). Proses Review atau Screening ISSI dilakukan setiap 6 bulan sekali yaitu pada bulan Mei dan November, selanjutnya diperbaharui pada awal bulan berikutnya. Adanya penyesuaian apabila adanya saham syariah yang baru tercatat maupun dihapuskan dari daftar DES. Proses perhitungan ISSI menggunakan metode rata-rata tertimbang yang merupakan bagian dari kapitalisasi pasar, dengan menggunakan tahun dasar pada awal penerbitan DES yaitu Desember 2007, sedangkan indeks ISSI diluncurkan pada tanggal 12 Mei 2011. (Widowati, 2018)

Nilai ISSI terus mengalami perkembangan. Hal tersebut disebabkan oleh semakin banyaknya saham-saham syariah yang diterbitkan oleh perusahaan penerbit saham. Disisi lain investor saham syariah juga semakin banyak.

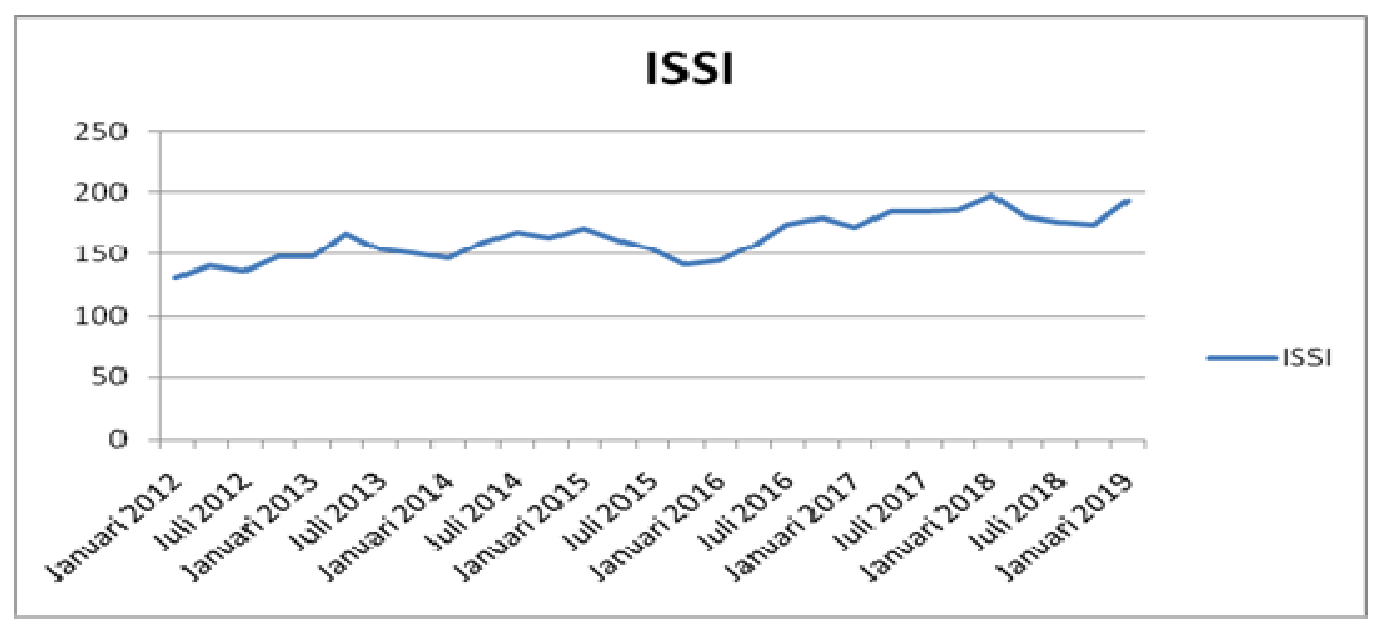

Sumber : Bursa Efek Indonesia, 2019

\section{Gambar 1 Pergerakan Indeks Harga Saham Syariah Indonesia (ISSI)}

Gambar 1 di atas menunjukkan pergerakan Indeks Saham Syariah Indonesia (ISSI) dari tahun 2012 sampai bulan Januari 2019. Pergerakan ISSI tersebut sangat fluktuatif tidak ada yang stagnan. Januari 2012 merupakan pergerakan ISSI yang terendah yaitu sebesar 130.737 poin. Pergerakan ISSI tertinggi terjadi pada bulan Januari 2018 yaitu sebesar 197.464 poin. Pergerakan ISSI yang fluktuatif tersebut menunjukkan ada beberapa faktor yang mempengaruhi pergerakan ISSI tersebut. Faktor tersebut bisa dari faktor ekonomi makro ataupun ekonomi global. Berfluktuatifnya pergerakan Indeks 
Saham Syariah Indonesia dari bulan Januari 2012 hingga januari 2019 menjadi perhatian khusus bagi para investor yang memperhatikan kondisi praktek di lapangan, guna menghadapi dari kondisi pasti maupun kondisi yang tidak pasti.

Faktor-faktor penting yang mampu mempengaruhi perkembangan indeks syariah menurut Syahrir (1995) dalam penelitian Ardana (2016) adalah oleh beberapa variabel makroekonomi dan moneter seperti Sertifikat Bank Indonesia Syariah, Inflasi, Jumlah Uang Beredar (JUB), nilai tukar dan lain-lain. Ardana (2016) melakukan penelitian mengenai pengaruh variabel makroekonomi terhadap Indeks Saham Syariah Indonesia (ISSI). Hasil penelitian Ardana (2016) menggunakan BI Rate, Nilai Tukar, Inflasi, SBIS, dan minyak dunia sebagai variabel makroekonomi. BI rate memiliki hubungan negative dan signifikan terhadap ISSI, Variabel Suku Bungan Nilai Tukar dan ISSI memiliki hubungan negative signifikan, tidak terdapat hubungan yang signifikan antara Inflasi dengan ISSI, terdapat hubungan positif yang signifikan antara harga minyak dunia dengan ISSI. (Ardana, 2016). Hasil penelitian Ardana (2016) ini tidak jauh berbeda dengan hasil penelitian Suciningtias dan Khoiroh (2015) bahwa inflasi, Nilai Tukar IDR/USR, Sertifikat Bank Indonesia Syariah (SBIS) dan harga minyak dunia bisa mempengaruhi ISSI secara signifikan.

Hubungan jumlah uang beredar dengan indeks harga saham ada yang negative dan positif. Hasil penelitian Menike (2006), Majid dan Yusof (2009), Hosseini dkk. (2011), menemukan hubungan negatif antara jumlah uang beredar dengan indeks harga saham. Penelitian ini menunjukkan bahwa tingkat bunga kurang merespon kenaikan jumlah uang beredar. Kenaikan uang beredar pada umumnya akan meningkatkan tingkat bunga untuk mengantisipasi kenaikan inflasi yang berlebihan. Ketika tingkat bunga relatif rendah terhadap jumlah uang beredar maka investor akan lebih tertarik menginvestasikan dananya di pasar modal. Peningkatan investasi yang terjadi di pasar modal akan meningkatkan permintaan saham. (Sudarsono, 2018)

Hubungan positif antara jumlah uang beredar dengan indeks harga saham berdasarkan hasil penelitian Asmy dkk (2010), Hussin dkk (2012), Bekhet dan Mugableh (2012) dan Pasaribu dan Firdaus (2013) menemukan hubungan positif antara jumlah uang beredar dengan harga saham di pasar modal. (Sudarsono, 2018)

Variabel-variabel ekonomi makro yang diuraikan di atas menunjukkan kemampuan dalam mempengaruhi keputusan investasi di Indonesia, terutama investor muslim yang berinvestasi di pasar modal syariah. Investasi di pasar modal syariah termasuk investasi yang aman khususnya pada saham syariah, namun tidak lepas dari perkembangan ekonomi makro. Kondisi tersebut menarik untuk diteliti khususnya pada perkembangan Indeks Saham Syariah Indonesia (ISSI). Bagaimana pengaruh dari variabel makroekonomi seperti nilai tukar, Sertifikat Bank Indonesia Syariah (SBIS), Sertifikat Bank Indonesia (SBI), dan Penawaran Uang (M2) terhadap pergerakan ISSI.

\section{KAJIAN TEORITIK DAN HIPOTESIS}

\section{Saham Syariah}

Huda dan Nasution (2014) mendefinisikan saham syariah adalah efek atau surat berharga yang memiliki konsep penyertaan modal kepada perusahaan dengan hak bagi hasil usaha yang tidak bertentangan dengan prinsip syariah. Saham syariah merupakan saham yang diterbitkan oleh emiten yang mana kegiatan bisnis \& tata cara pengelolaan bisnisnya tidak melanggar atau sejalan dengan prinsip-prinsip syariah. 


\section{Indeks Saham}

Indeks saham atau stock index merupakan harga yang diperoleh dari sebuah perhitungan baku sekumpulan kelompok saham yang yang berdasarkan kriteria tertentu menurut Suta (2000). Indeks saham dijadikan sebuah indikator perwakilan dari pergerakan harga dari seluruh saham. Indeks saham juga dapat digunakan sebagai indikator kondisi perekonomian suatu negara, yang dilihat dari kondisi indeks harga saham gabungan pada keseluruhan saham perusahaan go public dinegara tersebut. Cerminan keadaan perekonomian suatu negara apakah sedang lesu atau bergairah juga dapat dilihat dari indeks saham gabungan (Huda, 2014).

Ada beberapa jenis indeks pada pasar modal dunia, dikarenakan hampir setiap negara memiliki indeks saham, bahkan banyak negara memiliki lebih dari satu indeks saham. Contohnya Indonesia memiliki memiliki Indeks Harga Saham Gabungan (IHSG), Jakarta Islamic Index (JII), dan Indeks Saham Syariah Indonesai (ISSI), negara Jepang mempunyai indeks syariah Dow Jones Islamic Market Index Japan (DJIJP)dan negara Amerika Serikat memiliki Dow Jones Islamic Market US (IMUS), serta negara Eropa mempunyai Dow Jones Islamic Market Europe (DJIEU).

\section{Indeks Saham Syariah Indonesia (ISSI)}

ISSI mempunyai perbedaan dengan indeks JII (Jakarta Islamic Index). Perbedaan terletak pada ISSI merupakan keseluruhan saham syariah yang terdaftar di BEI. Sedangkan JII merupakan bagian atau subset dari saham syariah ISSI. (Widowati, 2018)

\section{Hasil Penelitian Yang Relevan}

Tesa (2012) melakukan penelitian dengan judul "Pengaruh Suku Bunga Internasional (Libor), Nilai Tukar Rupiah/US\$ Dan Inflasi Terhadap Indeks Harga Saham Gabungan Di Bursa Efek Indonesia Tahun 2000-2010". Hasil uji kointegrasi yang dilakukan oleh Tesa (2012) menunjukan bahwa variabel Suku Bunga Libor, Nilai Tukar Rupiah, Inflasi dan IHSG memiliki hubungan jangka panjang. Dari hasil analisa diketahui untuk uji Vector Autoregression menunjukan variabel yang paling memiliki kontribusi terbesar terhadap variabel Suku Bunga Libor adalah Suku Bunga Libor pada tahun sebelumnya. Untuk variabel Nilai Tukar Rupiah adalah Nilai Tukar Rupiah pada tahun sebelumnya. Sedangkan untuk variabel Inflasi dan IHSG adalah variabel Inflasi dan IHSG itu sendiri pada tahun sebelumnya. Hasil Impulse response function diketahui bahwa stabilitas pertama variabel Suku Bunga Libor, Nilai Tukar Rupiah, Inflasi dan IHSG yaitu pada jangka menengah sedangkan dalam jangka panjang semua variabel akan cenderung mengalami kestabilan. (Tesa, 2012)

Suciningtias dan Khoiroh (2015) melakukan penelitian dengan judul "Analisis Dampak Variabel Makro Ekonomi Terhadap Indeks Saham Syariah Indonesia (ISSI)". Variabel makro ekonomi yang digunakan dalam penelitian Suciningtias dan Khoiroh (2015) adalah Inflasi, Nilai tukar IDR/USD, Sertifikat Bank Indonesia Syariah (SBIS) dan Harga Minyak Dunia. Data penelitian yang digunakan merupakan data sekunder selama periode Mei 2011 sampai November 2014. Metode analisis yang digunakan dalam penelitian ini adalah metode analisis Regresi linier berganda. Hasil penelitian Suciningtias dan Khoiroh (2015) adalah Variabel Inflasi dan Nilai Tukar IDR/USD mempunyai pengaruh negatif signifikan terhadap Indek Saham Syariah Indonesia (ISSI) selama periode Mei 2011 sampai Nopember 2014. Di mana semakin tinggi tingkat inflasi dan Nilai Tukar IDR/USD akan menurukan Indek Saham Syariah Indonesia (ISSI). Variabel Sertifikat Bank Indonesia Syariah (SBIS) dan Harga Minyak Dunia mempunyai pengaruh tidak signifikan terhadap Indek Saham Syariah Indonesia (ISSI) selama periode Mei 2011 sampai Nopember 2014. Dimana perubahan tingkat imbalan 
Sertifikat Bank Indonesia Syariah (SBIS) dan perubahan harga minyak dunia tidak mampu mempengaruhi secara kuat pergerakan Indek Saham Syariah Indonesia (ISSI).

Rachmawati dan Laila (2015) melakukan penelitian dengan judul "Faktor Makroekonomi Yang Mempengaruhi Pergerakan Harga Saham Pada Indeks Saham Syariah Indonesia (ISSI) Di Bursa Efek Indonesia (BEI)". Penelitian Rachmawati dan Laila (2015) memiliki tujuan untuk menganalisa pengaruh variabel makroekonomi terhadap pergerakan harga saham di Indeks Saham Syariah Indonesia (ISSI). Variabel makroekonomi yang digunakan dalam penelitian Rachmawati dan Laila (2015) adalah suku bunga SBI, inflasi, dan nilai tukar rupiah. Metode analisa yang digunakan dalam penelitian Rachmawati dan Laila (2015) adalah metode regresi linear berganda, asumsi klasik, koefisiensi determinasi, uji F dan uji t. Data diperoleh dari laporan bulanan Bank Indonesia dan Bursa Efek Indonesia periode Januari 2012 hingga April 2015 sehingga jumlah observasi adalah 40. Hasil penelitian Rachmawati dan Laila (2015) menunjukkan bahwa tingkat inflasi secara parsial berpengaruh secara tidak signifikan terhadap pergerakan harga saham pada Indeks Saham Syariah Indonesia (ISSI). Suku bunga SBI secara parsial berpengaruh secara tidak signifikan terhadap pergerakan harga saham Indeks Saham Syariah Indonesia (ISSI). Nilai tukar rupiah secara parsial berpengaruh secara signifikan negatif terhadap Indeks Saham Syariah Indonesia (ISSI). Secara simultan, tingkat inflasi, suku bunga SBI dan nilai tukar rupiah berpengaruh secara signifikan terhadap Indeks Saham Syariah Indonesia (ISSI). (Rachmawati dan Laila, 2015)

Ardana (2016) melakukan penelitian dengan judul "Analisis Pengaruh Variabel MAkroekonomi Terhadap Indeks Saham Syariah Indonesia (Periode Mei 2011 - September 2015 Dengan Model ECM)". Penelitian Ardana (2016) ini bertujuan untuk menganalisis pengaruh variabel makroekonomi terhadap indeks saham syariah Indonesia. Variabel makroekonomi yang digunakan yaitu Suku Bunga Bank Indonesia (BI-rate), inflasi, nilai tukar rupiah, Sertifikat Bank Indonesia Syariah (SBIS) dan harga minyak dunia. Data yang digunakan oleh Ardana (2016) adalah data sekunder periode Mei 2011 sampai September 2015 dengan menggunakan model Error Correction Model (ECM). Hasil penelitian Ardana (2016) menunjukkan bahwa pengaruh variabel makroekonomi terhadap indeks saham syariah Indonesia dalam jangka pendek dan jangka panjang. Tidak terdapat hubungan jangka pendek antara variabel suku bunga BI dan ISSI, namun dikoreksi dalam hubungan jangka panjang sehingga hubungan antara variabel suku bunga BI dan ISSI adalah negative signifikan. Terdapat hubungan jangka pendek antara variabel nilai tukar dan ISSI, namun dikoreksi dalam hubungan jangka panjang sehingga hubungan antara variabel suku bunga nilai tukar dan ISSI adalah negatif signifikan. Tidak terdapat hubungan jangka pendek dan jangka panjang antara variabel inflasi dan ISSI. Terdapat hubungan jangka pendek dan jangka panjang antara variabel SBIS dan ISSI. Hasil peneliitian yang terakhir dari Ardana (2016) adalah tidak terdapat hubungan jangka pendek antara variabel harga minyak dunia dan ISSI, namun dikoreksi dalam hubungan jangka panjang sehingga hubungan antara variabel harga minyak dunia dan ISSI adalah positif signifikan.

Sri Hermuningsih, Hanita Yuniati, Mujino (2017) melakukan penelitian dengan judul “Apakah Indeks Saham Syariah Indonesia (ISSI) Memediasi Pengaruh Nilai Tukar terhadap Return Saham Syariah? Dengan menggunakan metode regresi berganda. Hasil penelitian Nilai tukar secara parsial mempunyai pengaruh terhadap variabel Indeks Saham Syariah Indonesia (ISSI) Pada sektor Property dan Real Estate selama periode Desember 2015Mei 2016. Hal ini menu njukkan bahwa apabila Nilai Tukar Rupiah Naik maka investasi saham di sector property dan Real Estate Pada Indeks Saham Syariah Indonesia akan meningkat. Nilai tukar (kurs) berpengaruh positif signifikan terhadap Return 
saham syariah melalui Indeks Saham Syariah Indonesia (ISSI) Pada sektor Property dan Real Estate selama periode Desember 2015-Mei 2016

Rega Saputra, Erdah Listriani dan Dinnul Alfian Akbar (2017) dalam penelitian yang berjudul Pengaruh Bi Rate, Inflasi, Nilai Tukar Rupiah, Dan Sertifikat Bank Indonesia Syariah (SBIS) Terhadap Indeks Saham Syariah Indonesia (ISSI) memberikan hasil (1) Secara simultan atau bersama-sama, BI Rate, Inflasi, Nilai Tukar Rupiah dan Sertifikat Bank Indonesia Syariah (SBIS) mempunyai pengaruh positif signifikan terhadap Indeks Saham Syariah Indonesia (ISSI) periode Juni 2011 hingga Mei 2015. (2). Secara parsial, BI Rate tidak berpengaruh signifikan terhadap Indeks Saham Syariah Indonesia (ISSI) periode Juni 2011 hingga Mei 2015. (3). Secara parsial, Inflasi tidak berpengaruh signifikan terhadap Indeks Saham Syariah Indonesia (ISSI) periode Juni 2011 hingga Mei 2015. (4). Secara parsial, Nilai Tukar Rupiah berpengaruh signifikan terhadap Indeks Saham Syariah Indonesia (ISSI) periode Juni 2011 hingga Mei 2015. (5). Secara parsial, Sertifikat Bank Indonesia Syariah (SBIS) tidak berpengaruh signifikan terhadap Indeks Saham Syariah Indonesia (ISSI) periode Juni 2011 hingga Mei 2015.

Widowati (2018) melakukan penelitian dengan judul "Analisis Integrasi Indeks Saham Syariah Dunia Dan Kinerja Variabel Ekonomi Makro Terhadap Indeks Saham Syariah Indonesia (ISSI)". Penelitian Widowati (2018) ini menganalisis pengaruh integrasi indeks saham syariah dunia dan variabel ekonomi makro terhadap pergerakan Indeks Saham Syariah Indonesia (ISSI).Penelitian Widowati (2018) ini menggunakan metode Vector Error Correction Model (VECM), dengan runtut waktu bulanan sejak Juni 2011 hingga April 2018. Indeks saham syariah dunia meliputi Dow Jones Islamic Market Index US (IMUS), Dow Jones Islamic Market Index Japan (DJIJP) dan Dow Jones Islamic Market Index Europe (DJIEU), sedangkan variabel ekonomi makro meliputi tingkat suku bunga (BI rate), nilai tukar rupiah terhadap dollar US (IDR/USD) dan harga minyak dunia. Hasil penelitian Widowati (2018) menunjukan bahwa pada jangka panjang variabel BI rate, IMUS, DJIJP, DJIEU berpengaruh terhadap pergerakan ISSI. Sedangkan pada jangka pendek hanya variabel BI rate yang berpengaruh terhadap ISSI. Saham syariah menjadi solusi bagi para investor saham yang sebelumnya hanya mengenal saham konvensional.

Sudarsono (2018) melakukan penelitian dengan judul "Indikator Makroekonomi dan Pengaruhnya Terhadap Indeks Saham Syariah Indonesia”. Penelitian Sudarsono (2018) bertujuan untuk menganalisi pengaruh variabel penawaran uang (M2), indek harga konsumen (CPI), nilai tukar (ER), BI rate (BIRATE), sertifikat Bank Indonesia syariah (SBIS) terhadap Indek Saham Syariah Indonesia (ISSI). Untuk melihat pengaruh diantara variabel tersebut digunakan vector autoregression. Data yang digunakan dalam penelitian ini adalah data sekunder dari Januari 2012 sampai Desember 2016. Dari hasil regresi jangka panjang ditemukan bahwa CPI berpengaruh positif terhadap ISSI dan M2, ER dan BIRATE berpengaruh negatif terhadap ISSI. Hasil uji Granger Causality menunjukkan bahwa ada pengaruh kausalitas BIRATE dan CPI, serta CPI dan SBIS, tetapi terdapat hubungan satu arah diantaranya adalah ISSI terhadap ER, M2 terhadap BIRATE, dan SBIS dengan BIRATE. (Sudarsono, 2018).

Rachman dan Herianingrum (2018) melakukan penelitian dengan judul "Pengaruh Instrumen Sertifikat Bank Indonesia (SBI), Pasar Uang Antar Bank (PUAB), Sertifikat Bank Indonesia Syariah (SBIS), Pasar Uang Antar Bank Syariah (PUAS) Terhadap M2 Di Indonesia Periode 2009-2016". Metode analisa yang digunakan dalam penelitian Rachman dan Herianingrum (2018) adalah VAR/VECM. Data yang digunakan adalah Tingkat Sertifikat Bank Indonesia (SBI) pada triwulan I 2009 - triwulan ke III 2016. Tingkat Sertifikat Bank Indonesia Syariah (SBIS) pada triwulan I 2009 - 
triwulan ke III 2016. Tingkat Pasar Uang Antar Bank (PUAB) pada triwulan I 2009 - triwulan ke III 2016. Tingkat Pasar Uang Antar Bank Syariah (PUAS) pada triwulan I 2009 - triwulan ke III 2016, dan Tingkat Jumlah Uang Beredar (M2) pada triwulan I 2009 - triwulan ke III 2016. Hasil penelitian Rachman dan Laila (2018) adalah SBI memiliki hubungan positif yang signifikan pada jangka panjang. PUAB signifikan dalam jangka panjang. SBIS signifikan pada jangka panjang. PUAS juga signifikan dalam jangka panjang mempengaruhi penawaran uang (M2).

Kholidah et.al (2019) melakukan penelitian dengan judul "Analisis Kinerja Reksadana Saham Syariah Dengan Metode Sharpe, Treynor, Jensen, M², Dan T'T”. Penelitian Kholidah et.al (2019) ini bertujuan untuk menganalisis kinerja reksadana saham syariah di Indonesia yang diukur menggunakan risiko dan return berdasarkan metode Sharpe, Treynor, Jensen, $\mathrm{M}^{2}$ dan TT periode April - September 2018. Jenis penelitian ini adalah deskriptif kuantitatif. Berdasarkan metode Sharpe dan Treynor menunjukkan hasil yang sama, yaitu tidak terdapat reksadana saham syariah yang berkinerja positif. Selama periode pengamatan (April - September 2018) menggunakan metode Jensen, $\mathrm{M}^{2}$ dan TT hanya ada dua reksadana yang memiliki kinerja terbaik diantara reksadana lainnya karena mampu outperform dari SBIS dan ISSI selama 6 bulan. Reksadana tersebut adalah TRIM Syariah Saham dan Batavia Dana Saham Syariah, oleh karena itu kedua reksadana tersebut adalah reksadana yang layak dijadikan pilihan berinvestasi di tahun 2019. (Kholidah et.al, 2019)

Perbedaan penelitian ini dengan penelitian sebelumnya lebih pada tahun kajian yang berbeda, variabel penelitian berbeda dan beberapa penelitian berbeda dalam metode penelitian.

\section{DATA DAN METODE}

\section{Subjek dan Objek Penelitian}

Subjek dalam penelitian ini adalah data sekunder yang ada di Bank Indonesia dan Bursa Efek Indonesia. Sementara objek dalam penelitian ini adalah mengenai Indeks Harga Saham Syariah dan Variabel Makro Ekonomi

\section{Populasi dan Sampel}

Populasi dalam penelitian ini adalah data sekunder Indeks Saham Syariah Indonesia, Nilai Tukar, Sertifikat Bank Indonesia Syariah, Sertifikat Bank Indonesia, dan Jumlah Uang Beredar/Penawaran Uang. Sampel dalam penelitian ini data sekunder kelima variabel dalam rentang waktu Januari 2016 sampai Januari 2019. Data yang digunakan adalah per bulan, sehingga total data yang akan digunakan adalah sebesar 148 data.

\section{Variabel dan Definisi Operasional Variabel Penelitian}

Variabel dalam penelitian ini dapat diklasifikasikan menjadi:

1. Variabel Independen, yakni variabel yang tidak diprediksi oleh variabel lain dalam model (Ferdinand, 2002). Dalam penelitian ini variabel independen adalah nilai tukar (X1), SBIS (X2), SBI (X3), dan Penawaran Uang (X4)

2. Variabel Dependen, yakni variabel yang diprediksikan oleh satu atau beberapa variabel yang lain dalam model (Ferdinand, 2002). Variabel dependen dalam penelitian ini adalah Indeks Saham Syariah Indonesia (ISSI) (Y) 


\section{Definisi Operasional Variabel Penelitian}

1. Nilai Tukar (Kurs), Nilai tukar (kurs) merupakan harga suatu mata uang domestic terhadap mata uang negara lain, pada penelitian ini menggunakan Kurs tengah terhadap Rupiah (USD/IDR) yang diumumkan oleh Bank Indonesia periode bulanan.

2. Sertifikat Bank Indonesia Syariah, Sertifikat Bank Indonesia Syariah (SBIS) merupakan instrumen Operasi Pasar Terbuka (OPT) yang menggunakan prinsip syariah, SBIS merupakan instrument pengendalian moneter yang bersifat kontraksi. Apabila perbankan mengalami likuiditas, SBIS dapat dijadikan sebagai membantu kesediaan dana jangka pendek dengan prinsip bagi hasil/imbalan yang sudah ditetapkan sebelumnya. SBIS menggunakan akad juâlah yaitu bagi hasil/ujro yang sesuai dengan prinsip syariah. Data dalam penelitian ini dinyatakan dalam Miliar rupiah pada periode Januari 2016-Januari 2019 dengan data yang diambil bulanan yang diperoleh dari Statistik Ekonomi dan Keuangan Indonesia (SEKI) yang dapat diakses melalui web resmi Bank Indonesia(www.bi.go.id).

3. Sertifikat Bank Indonesia (BI rate), BI rate adalah suku bunga yang ditetapkan Bank Indonesia dan diumumkan kepada masyarakat umum, yang mencerminkan sikap kebijakan moneter pemerintah. Data suku bunga dalam peneltian diambil dari data BI rate periode bulanandan BI 7-Days Repo Rate dalam periode bulanan yang diumumkan oleh Bank Indonesia.

4. Jumlah Uang Beredar/Penawaran Uang (M2), Broad Money (M2) merupakan uang beredar yang terdiri dari uang karta, uang giral (giro yang didominasi oleh rupiah), deposit berjangka dan saldo tabungan milik masyarakat. Data yang diambil oleh peneliti dinyatakan dalam Miliar rupiah dengan pengumpulan data bulanan Januari tahun 2016 hingga Januari tahun 2016, data diperoleh dari Statistik Ekonomi dan Keuangan Indonesia (SEKI) yang diakses melalui web resmi Bank Indonesia, (www.bi.go.id)

5. Indeks Saham Syariah Indonesia (ISSI), Indeks Saham Syariah Indonesia (ISSI) adalah Indeks harga saham berbasis syariah yang ada di Indonesia. Mencerminkan keseluruhan saham yang terdaftar di Bursa Efek Indonesia (BEI). Metode penghitungan indeks ISSI menggunakan rata-rata tertimbang dari kapitalisasi pasar. Tahun dasar yang digunakan dalam perhitungan Indek Saham Syariah Indonesia (ISSI) adalah Januari 2016 sampai Januari 2019. Adapun cara perhitungan ISSI sebagai berikut:

$$
I S S I-\frac{\sum H_{t}}{\sum H_{0}} x 100 \%
$$

$\Sigma$ Ht ISSI $=$ Total harga semua saham pada waktu yang berlaku

$\Sigma$ Ho ISSI $=$ Total harga semua saham pada waktu dasar $(\operatorname{tahun} 2007)$

\section{Jenis dan Metode Pengumpulan Data}

Jenis data dalam penelitian ini merupakan data kuantitatif dengan menggunakan data sekunder. Pengumpulan data pada penelitian ini dilakukan dengan pengambilan data sekunder yang tersedia di website Bank Indonesia dan Bursa Efek Indonesia serta Otoritas Jasa Keuangan.

\section{Metode Analisis Data}

Metode analisis data yang digunakan dalam penelitian ini adalah analisis kuantitatif model komparasi adalah teknik analisis statistik yang bertujuan untuk membandingkan antara kondisi dua buah kelompok atau lebih. Untuk menguji pengaruh makroekonomi daerah terhadap ISSI, peneliti menggunakan analisis Vector Autoregression (VAR). Metodelogi VAR dikembangkan oleh Christopher A. 
Sims dengan mempertimbangkan meminimalisir pendekatan teori agar mampu menangkap fenomena ekonomi dengan baik sehingga diasumsikan semua variabel yang digunakan adalah dependen. Didalam penggunaan VAR, menurut Widarjono (2013) perlu memperhatikan dua hal, yaitu:

1. Semua variabel yang diyakini saling berhubungan dimasukkan ke dalam variabel dependen.

2. Untuk melihat hubungan antar variabel dibutuhkan sejumlah kelambanan variabel yang digunakan. Kelambanan ini dibutuhkan untuk menangkap dampak dari variabel terhadap variabel lain.

Pemilihan dengan metode analisis VAR dalam penelitian ini bertujuan untuk meminimalkan pendekatan teori agar dapat menangkap fenomena ekonomi dengan baik dan sebuah gejala makroekonomi tidak akan berpengaruh secara langsung terhadap variabel yang diteliti, tetapi memerlukan selang waktu. Dengan menggunakan metode analisis ini diharapkan dapat mengetahui selang waktu optimal yang berpengaruh terhadap variabel yang diteliti. Adapun di bawah ini rumus matematika pembentukan metode analisis VAR:

$Y_{n t}=\beta_{01}+\Sigma_{i=1}^{p} \beta_{i n} Y_{1 t-i}+\Sigma_{i=1}^{p} \alpha_{i n} Y_{2 t-i}+\cdots+\Sigma_{i=1}^{p} \eta_{i n}+e_{n t}$

Dimana ukuran dari $\alpha$ dan $\beta$ mempunyai dimensi $\mathrm{N}$ x r, $\mathrm{N}$ merupakan jumlah perubah dan $\mathrm{r}$ adalah derajat kointegrasi. $\mathrm{P}=$ panjang kelambanan. Kemudia model VAR yang akan digunakan dengan menggunakan 5 variabel adalah:

$$
\begin{aligned}
& I S S I_{t}=\beta_{0}+\Sigma_{i=1}^{p} \beta_{1} I S S I_{t-i}+\Sigma_{i=1}^{p} \beta_{2} N T_{t-1}+\Sigma_{i=1}^{p} \beta_{3} S B I S_{t-1}+\Sigma_{i=1}^{p} \beta_{4} S B I_{t-1}+ \\
& \Sigma_{i=1}^{p} \beta_{5} J U B_{t-1}+i t \\
& N T_{t}=\beta_{0}+\Sigma_{i=1}^{p} \beta_{1} N T_{t-i}+\Sigma_{i=1}^{p} \beta_{2} I S S I_{t-1}+\Sigma_{i=1}^{p} \beta_{3} S B I S_{t-1}+ \\
& \Sigma_{i=1}^{p} \beta_{4} S B I_{t-1}+\Sigma_{i=1}^{p} \beta_{5} J U B_{t-1}+i t \\
& S B I S_{t}=\beta_{0}+\Sigma_{i=1}^{p} \beta_{1} S B I S_{t-i}+\Sigma_{i=1}^{p} \beta_{2} I S S I_{t-1}+\Sigma_{i=1}^{p} \beta_{3} N T_{t-1}+ \\
& \Sigma_{i=1}^{p} \beta_{4} S B I_{t-1}+\Sigma_{i=1}^{p} \beta_{5} J U B_{t-1}+i t \\
& S B I_{t}=\beta_{0}+\Sigma_{i=1}^{p} \beta_{1} S B I_{t-i}+\Sigma_{i=1}^{p} \beta_{2} I S S I_{t-1}+\Sigma_{i=1}^{p} \beta_{3} N T_{t-1}+ \\
& \Sigma_{i=1}^{p} \beta_{4} S B I S_{t-1}+\Sigma_{i=1}^{p} \beta_{5} J U B_{t-1}+i t \\
& J U B_{t}=\beta_{0}+\Sigma_{i=1}^{p} \beta_{1} J U B_{t-i}+\Sigma_{i=1}^{p} \beta_{2} I S S I_{t-1}+\Sigma_{i=1}^{p} \beta_{3} N T_{t-1}+ \\
& \Sigma_{i=1}^{p} \beta_{4} S B I S_{t-1}+\Sigma_{i=1}^{p} \beta_{5} S B I_{t-1}+i t
\end{aligned}
$$

Dimana:

ISSI $t=$ Indeks Harga Saham Syariah Indonesia pada bulan $\mathrm{t}$

NTt $-1=$ Nilai Tkar pada bulan $\mathrm{t}-\mathrm{n}$

SBISt $-1=$ Sertifikat Bank Indonesia Syariah pada bulan $\mathrm{t}-\mathrm{n}$

SBI $t-1=$ Sertifikat Bank Indonesia pada bulan $\mathrm{t}-\mathrm{n}$

JUB $t-1=$ Jumlah Uang Beredar pada bulan $\mathrm{t}-\mathrm{n}$

$\beta=$ Konstanta

$\beta 1, \beta 2 \ldots \beta n=$ Parameter dalam bentuk matriks polinomial dengan lag operator $\mathrm{p}$

it $=$ error term

$\mathrm{p}=$ panjang lag $\mathrm{VAR}$ 


\section{ANALISIS DAN HASIL}

\section{Uji Stasionaritas}

Uji stasioneritas data pada seluruh variabel dengan Augmented Dickey-Fuller Test (ADF) dengan software Eviews 5.0. Kriteria yang digunakan adalah kelambanan (lag) Akaike Information Criterion (AIC). Jika nilai Test Critical Value lebih besar dari nilai t- Statistic berarti data tidak ada stasioner, sebaliknya jika Test Critical V alue lebih kecil dari nilai t-Statistic berarti data stationer.

Tabel 2. Hasil Uji Stasioneritas Data dengan ADF Pada Level

\begin{tabular}{cccccc}
\hline \multirow{2}{*}{ Variabel } & \multicolumn{3}{c}{ Test Critical Value: Level } & \multirow{2}{*}{ t-Statistic } & \multirow{2}{*}{ Prob. ${ }^{*}$} \\
\cline { 2 - 4 } & $1 \%$ & $5 \%$ & $10 \%$ & & \\
\hline NT & -3.626784 & -2.945842 & -2.611531 & -1.808590 & 0.3705 \\
SBIS & -3.632900 & -2.948404 & -2.612874 & -2.149186 & 0.2277 \\
BI & -3.626784 & -2.945842 & -2.611531 & -1.926352 & 0.3170 \\
JUB & -3.670170 & -2.963972 & -2.621007 & -1.391233 & 0.5732 \\
ISSI & -3.626784 & -2.945842 & -2.611531 & -2.850659 & 0.0614 \\
\hline
\end{tabular}

Keterangan: * = Stasioner

Sumber: Hasil uji stasioner dengan Eviews 5.0, data sudah diolah kembali.

Tabel 2 di atas menunjukkan bahwa uji stasioneritas pada level, seluruh data tidak stasioner pada derajat kepercayaan 1\%,5\% maupun 10\%, sehingga perlu dilakukan uji stasioneritas data lebih lanjut yaitu pada pembedaan pertama (first difference). Hasil uji stasioneritas pada first difference terlihat pada Tabel 3 .

Tabel 3 Hasil Uji Stasioneritas Data dengan ADF pada Pembedaan Pertama

\begin{tabular}{|c|c|c|c|c|c|}
\hline \multirow[t]{2}{*}{ Variabel } & \multicolumn{3}{|c|}{ Test Critical V alue: Level } & \multirow[t]{2}{*}{$\mathrm{t}-$ Statistic } & \multirow[t]{2}{*}{ Prob. * } \\
\hline & $1 \%$ & $5 \%$ & $10 \%$ & & \\
\hline NT & -3.632900 & -2.948404 & -2.612874 & -7.500367 & 0.0000 \\
\hline SBIS & -3.632900 & -2.948404 & -2.612874 & -4.525554 & 0.0009 \\
\hline $\mathrm{BI}$ & -3.632900 & -2.948404 & -2.612874 & -5.911102 & 0.0000 \\
\hline JUB & -3.670170 & -2.963972 & -2.621007 & -10.48184 & 0.0000 \\
\hline ISSI & -3.632900 & -2.948404 & -2.612874 & -4.424141 & 0.0012 \\
\hline
\end{tabular}

Keterangan: $*=$ Stasioner

Sumber: Hasil uji stasioner dengan Eviews 5.0, data sudah diolah kembali.

Tabel 3 di atas terlihat bahwa pada uji stasioneritas data pada pembeda pertama semua data sudah stasioner pada derjat kepercayaan 1\%,5\% maupun 10\%. Artinya, data stasioner pada pembedaan pertama. Karena data stasioner pada derajat yang sama.

\section{Uji Kointegritas}

Data dalam penelitian ini sudah stasioner pada pembedaaan pertama, maka tahap berikutnya adalah uji kointegritas. Uji kointegritas dilakukan untuk mengetahui hubungan jangka panjang antar variabel. Uji kointegritas data dilakukan dengan Johansen Cointegration Test dengan asumsi tidak ada linear deterministic trend. Hasilnya jika Trace Statistic nya lebih kecil dibandingkan dengan nilai Critical Value maka variabelvariabel tidak terkointegrasi, sebaliknya jika nilai Trace Statistic lebih besar dibandingkan dengan nilai Critical V alue, maka variabel-variabel terkointegrasi. Hasil uji kointegrasi dengan menggunakan Johansesn Cointegration Test terlihat pada Tabel 4. Hasil tes uji kointegrasi pada tabel 4 menunjukkan nilai trace 
statistic lebih besar dari nilai ciritical value pada tingkat level 5\%, sehingga H0 ditolak, berarti model ini terdapat kointegrasi.

Tabel 4 Hasil Johansen Cointegration Test dengan Eviews

\begin{tabular}{|c|c|c|c|c|}
\hline \multicolumn{5}{|c|}{ Date: 03/22/19 Time: 10:12 } \\
\hline \multicolumn{5}{|c|}{ Sample (adjusted): 2016M03 2019M01 } \\
\hline \multicolumn{5}{|c|}{ Included observations: 35 after adjustments } \\
\hline \multicolumn{5}{|c|}{ Trend assumption: Linear deterministic trend } \\
\hline \multicolumn{5}{|c|}{ Series: LNBI LNISSI LNJUB LNNT LNSBIS } \\
\hline \multicolumn{5}{|c|}{ Lags interval (in first differences): 1 to 1} \\
\hline \multicolumn{5}{|c|}{ Unrestricted Cointegration Rank Test (Trace) } \\
\hline Hypothesized & & Trace & 0.05 & \\
\hline No. of CE(s) & Eigenvalue & Statistic & Critical Value & Prob.** \\
\hline None ${ }^{*}$ & 0.628384 & 79.94610 & 69.81889 & 0.0062 \\
\hline At most 1 & 0.506993 & 45.29981 & 47.85613 & 0.0852 \\
\hline At most 2 & 0.261337 & 20.54671 & 29.79707 & 0.3865 \\
\hline At most 3 & 0.210205 & 9.944751 & 15.49471 & 0.2850 \\
\hline At most 4 & 0.047013 & 1.685381 & 3.841466 & 0.1942 \\
\hline $\begin{array}{l}\text { Trace test indica } \\
* \text { denotes rejecti } \\
* * \text { MacKinnon- }\end{array}$ & $\begin{array}{l}\text { cointegratin } \\
\text { f the hypothe } \\
\text {-Michelis (19) }\end{array}$ & $\begin{array}{l}\text { at the } 0.05 \\
\text { e } 0.05 \text { level } \\
\text { lues }\end{array}$ & & \\
\hline
\end{tabular}

Sumber: Hasil uji stasioner dengan Eviews 5.0, data sudah diolah kembali.

\section{Estimasi VAR dan Analisis}

Penelitian ini melakukan estimasi model dengan menggunakan Restricted Vector Autoregression (Restricted $V A R)$ / Vector Error Correction Model (VECM) berdasarkan hasil uji stasioneritas data dan uji kointegritas data.

Estimasi VECM menggunakan kriteria panjang kelambanan (lag) Akaike Information Criterion (AIC). AIC adalah panjang kelambanan yang menghasilkan nilai AIC terkecil. Hasil estimasi yang dilakukan ternyata AIC terkecil didapat ketika estimasi pada menggunakan Lag 1 yang menghasilkan nilai AIC sebesar -4,177107. Dengan demikian estimasi VAR-VECM menggunakan Lag 1. Tahap selanjutnya mendapatkan hasil Impulse Response dan V ariance Decomposition variabel.

\section{Hasil Impulse Response}

Hasil impulse response untuk dapat melihat respon ISSI ketika ada kejutan dari Nilai Tukar (NT), Sertifikat Bank Indonesia Syariah (SBIS), BI Rate (BI) dan Jumlah Uang Beredar (JUB). Hasil ini dapat digambarkan dengan gambar grafik. Penggambaran Impulse Response Function (IRF) dengan grafik untuk memudahkan melihat pergerakan respon masing-masing variabel terhadap kejutan variabel lainnya maupun dirinya sendiri.

Sumbu horizontal pada grafik merupakan waktu dalam periode satu bulan kedepan setelah terjadinya kejutan (shock), sementara sumbu vertikal adalah tingkat perubahan bukan nilai perubahan 
karena data stasioner pada diferensi (turunan). Pergerakan respon yang semakin menjauh dari titik keseimbangan (convergence) bermakna bahwa kejutan suatu variabel sebesar satu standar deviasi berpengaruh semakin menguat atau permanen terhadap variabel itu sendiri atau variabel lainnya. Sebaliknya, pergerakan respon yang semakin mendekati titik keseimbangan (convergence) bermakna bahwa kejuta suatu variabel sebesar satu standar deviasi berpengaruh semakin melemah atau tidak permanen terhadap variabel itu sendiri atau variabel lainnya, dan tidak lagi berpengaruh ketika berada di titik keseimbangan. Respon positif menunjukkan bahwa kejutan suatu variabel berpengaruh positif terhadap variabel itu sendiri atau variabel lainnya, sedangkan respon negatif menunjukkan bahwa kejuta suatu variabel berpengaruh negative terhadap variabel itu sendiri atau variabel lainnya terdorong semakin menurun.

\section{Respon Variabel Indeks Saham Syariah Indonesia (ISSI) Terhadap Kejutan Variabel Lain dan Kejutannya Sendiri}

Gambar 2 menunjukkan selama 37 periode (bulan) respon Indeks Saham Syariah Indonesia (ISSI) ratarata memberi respon positif terhadap kejutan variabel : Indeks Saham Syariah Indonesia (ISSI), Nilai Tukar (NT), BI Rate (BI), dan Jumlah Uang Beredar (JUB). Gambar 2 juga menunjukkan bahwa Indeks Saham Syariah Indonesia (ISSI) memberikan respon negative terhadap kejutan dari variabel Seritifikat Bank Indonesia Syariah (SBIS).

Response to Cholesky One S.D. Innovations
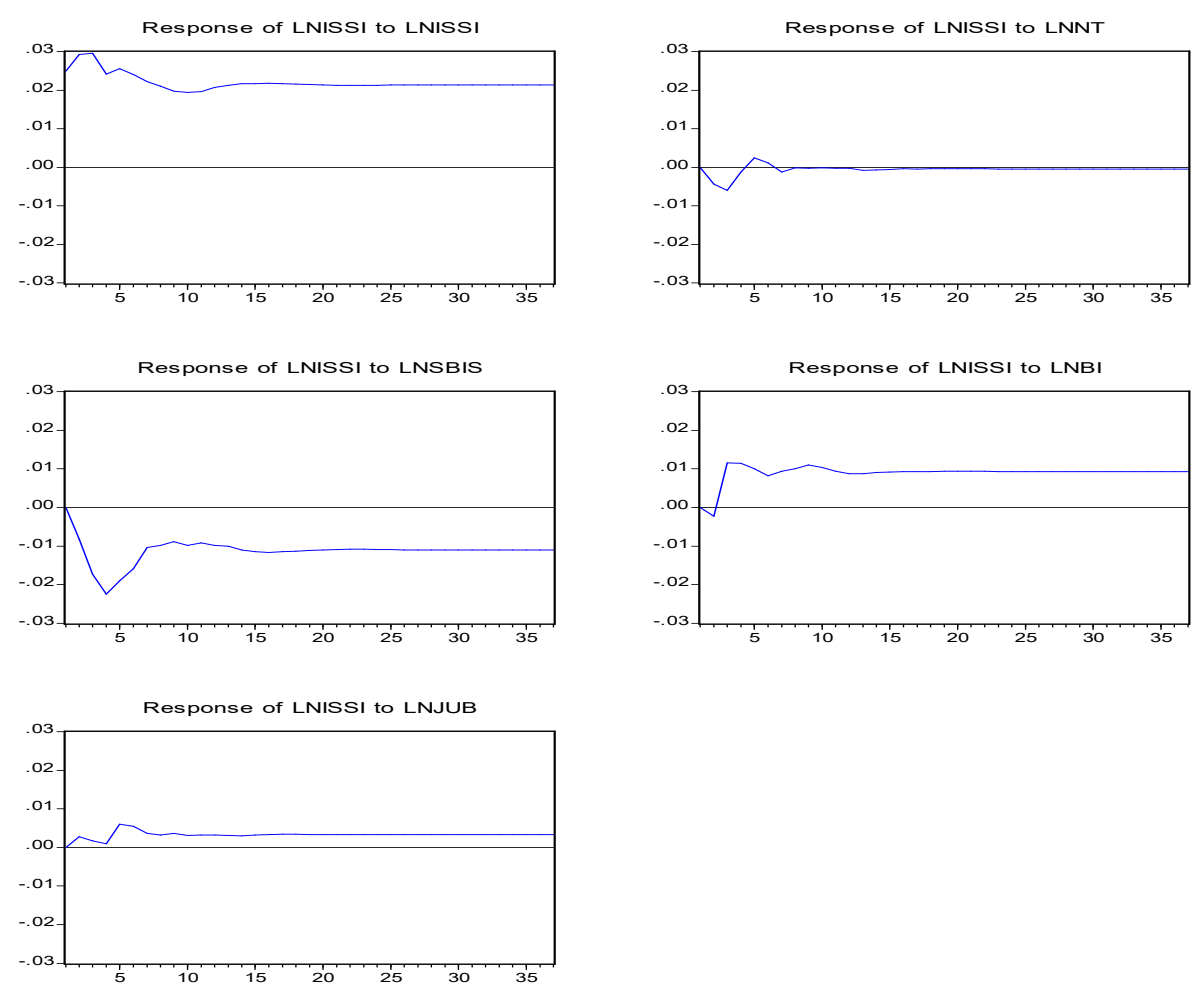

Sumber: BI dan OJK, data diolah, 2019

\section{Gambar 2}

\section{Respon Variabel Indeks Saham Syariah Indonesia (ISSI) terhadap Kejutan Variabel Lainnya dan Kejutan Sendiri}


Respon Indeks Saham Syariah Indonesia (ISSI) negative rata-rata sebesar -0,013\% terhadap kejutan Nilai Tukar (NT), hal ini bermakna kejutan Nilai Tukar (NT) sebesar satu standar deviasi berpengaruh mendorong menurunnya Indeks Saham Syariah Indonesia (ISSI) rata-rata sebesar 0,013\%. Respon Indeks Saham Syariah Indonesia (ISSI) negative rata-rata sebesar -0,217\% terhadap kejutan Sertifikat Bank Indonesia Syariah (SBIS), hal ini bermakna kejutan Sertifikat Bank Indonesia Syariah (SBIS) sebesar satu standar deviasi berpengaruh mendorong menurunnya Indeks Saham Syariah Indonesia (ISSI) rata-rata sebesar -0,217\%.

Respon Indeks Saham Syariah Indonesia (ISSI) positif rata-rata sebesar 0,162\% terhadap kejutan tingkat suku bunga BI Rate (BI), hal ini bermakna kejutan tingkat suku bunga BI Rate (BI) sebesar satu standar deviasi berpengaruh mendorong meningkatmya Indeks Saham Syariah Indonesia (ISSI) rata-rata sebesar 0,162\%. Respon Indeks Saham Syariah Indonesia (ISSI) positif rata-rata sebesar 0, 06\% terhadap kejutan Jumlah Uang Beredar (JUB). Hasil ini menunjukkan bahwa kejutan Jumlah Uang Beredar (JUB) sebesar satu standar deviasi mendorong meningkatnya Indeks Saham Syariah Indonesia (ISSI) sebesar 0, 06\%.

Respon Indeks Saham Syariah Indonesia (ISSI) terhadap kejutan ISSI sendiri adalah positif rata-rata sebesar 0,430\%. Hal ini berarti bahwa kejutan Indeks Saham Syariah Indonesia (ISSI) sebesar satu standar deviasi mendorong meningkatnya Indeks Saham Syariah Indonesia (ISSI) sendiri sebesar $0,430 \%$.

\section{Respon Variabel Nilai Tukar (NT) Terhadap Kejutan Variabel Lain dan Kejutannya Sendiri}

impulse respon variabel Nilai Tukar dengan kejutan variabel lain dan kejutan variabel Nilai Tukar (NT) sendiri. Nilai Tukar (NT) memberi respon negative rata-rata sebesar -0,146\% terhadap kejutan variabel Indeks Saham Syariah Indonesia (ISSI). Hasil ini menunjukkan bahwa setiap kejutan Indeks Saham Syariah Indonesia (ISSI) sebesar satu standar deviasi maka mendorong menurunnya variabel Nilai Tukar (NT) rata-rata sebesar $-0,146 \%$.

Variabel Nilai Tukar (NT) memberi respon positif rata-rata sebesar 0,189\% terhadap kejutan dari variabel Sertifikat Bank Indonesia Syariah (SBIS). Nilai ini menunjukkan bahwa setiap kejutan dari Sertifikat Bank Indonesia Syariah (SBIS) sebesar satu standar deviasi, maka mendorong meningkatnya Nilai Tukar (NT) rata-rata sebesar 0,189\%. Respon variabel Nilai Tukar (NT) pada tabel 4.5 terhadap kejutan dari variabel tingkat suku bunga BI Rate (BI) adalah negative dengan nilai rata-rata sebesar - 0 , 0588\%. Hasil ini menunjukkan bahwa setiap adanya kejutan dari BI Rate (BI) sebesar satu standar deviasi, maka akan mendorong menurunnya Nilai Tukar (NT) rata-rata sebesar -0,0588\%.

Kejutan dari variabel Jumlah Uang Beredar (JUB) pada tabel 3 diatas memberi respon positif dari variabel Nilai Tukar. Respon Nilai Tukar (NT) yang positif rata-rata sebesar 0,008\% terhadap kejutan variabel Jumlah Uang Beredar (JUB). Hasil tersebut menunjukkan bahwa setiap kejutan dari variabel Jumlah Uang Beredar (JUB) sebesar satu standar deviasi, maka mendorong meningkatnya variabel Nilai Tukar (NT) rata-rata sebesar 0,008\%. 
Accumulated Response to Cholesky One S.D. Innovations
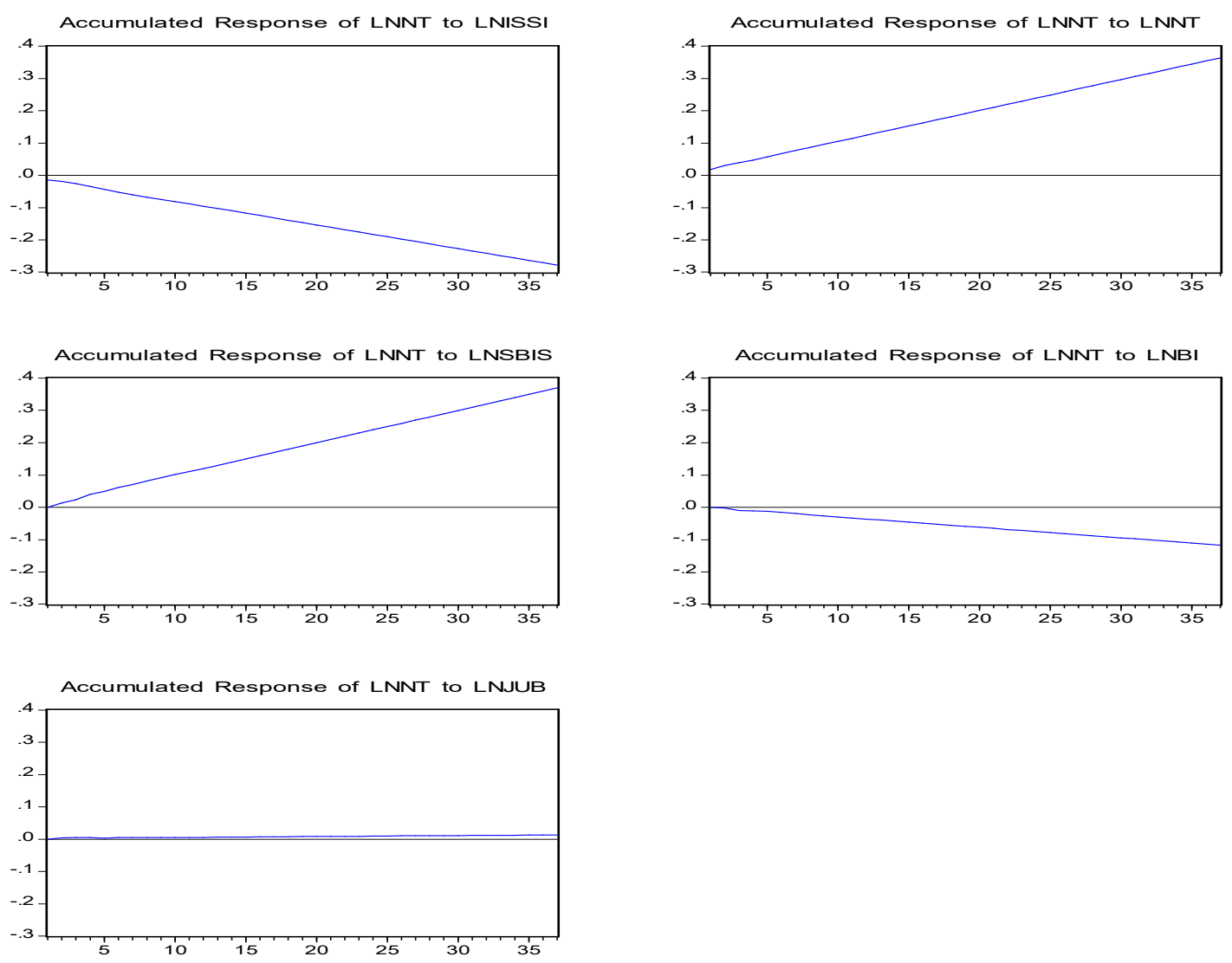

Sumber: BI dan OJK, data diolah, 2019

Gambar 3. Respon Variabel Nilai Tukar terhadap Kejutan Variabel Lain dan Sendiri

\section{Respon Variabel Sertifikat Bank Indonesia Syariah (SBIS) Terhadap Kejutan Variabel Lain dan Kejutannya Sendiri}

Variabel Sertifikat Bank Indonesia Syariah (SBIS) memberi respon positif rata-rata sebesar 1,197\% terhadap kejutan dari variabel Indeks Saham Syariah Indonesia (ISSI). Hasil ini juga menunjukkan bahwa setiap kejutan dari variabel Indeks Saham Syariah (ISSI) sebesar satu standar deviasi, maka mendorong meningkatnya Sertifikat Bank Indonesia Syariah (SBIS) rata-rata sebesar 1,197\%.

Respon Sertifikat Bank Indonesia Syariah (SBIS) negative rata-rata sebesar -0,234\% terhadap kejutan dari variabel Nilai Tukar (NT). Arti dari nilai tersebut adalah setiap kejutan dari variabel Nilai Tukar (NT) sebesar satu standar deviasi, maka akan mendorong menurunnya Sertifikat Bank Indonesia Syariah (SBIS) rata-rata sebesar $-0,234 \%$.

Sertifikat Bank Indonesia Syariah (SBIS) menunjukkan respon negative terhadap kejutan dari BI Rate (BI). Respon negative tersebut rata-rata sebesar -0,141\%. Hal ini menunjukkan bahwa setiap kejutan BI Rate (BI) sebesar satu standar deviasi, maka akan mendorong menurunnya tingkat Sertifikat Bank Indonesia Syariah (SBIS) rata-rata sebesar -0,141\%.

Gambar 4 juga menunjukkan respon negative Sertifikat Bank Indonesia Syariah (SBIS) ratarata sebesar -0, 08\% terhadap kejutan variabel Jumlah Uang Beredar (JUB). Hasil ini berarti setiap kejutan dari variabel Jumlah Uang Beredar (JUB) sebesar satu standar deviasi, maka akan mendorong 
menurunnya tingkat Sertifikat Bank Indonesia Syariah (SBIS) rata-rata sebesar -0, 08\%. Respon negative juga diberikan oleh Variabel Sertifikat Bank Indonesia Syariah (SBIS) terhadap kejutan dari variabel Sertifikat Bank Indonesia Syariah (SBIS) itu sendiri. Nilai rata-rata respon negative tersebut adalah sebesar - $0,059 \%$. Hasil ini berarti bahwa setiap kejutan dari Sertifikat Bank Indonesia Syariah (SBIS) sebesar satu standar deviasi, maka akan mendorong menurunnya tingkat Sertifikat Bank Indonesia Syariah (SBIS) rata-rata sebesar $-0,059 \%$.

Accumulated Response to Cholesky One S.D. Innovations
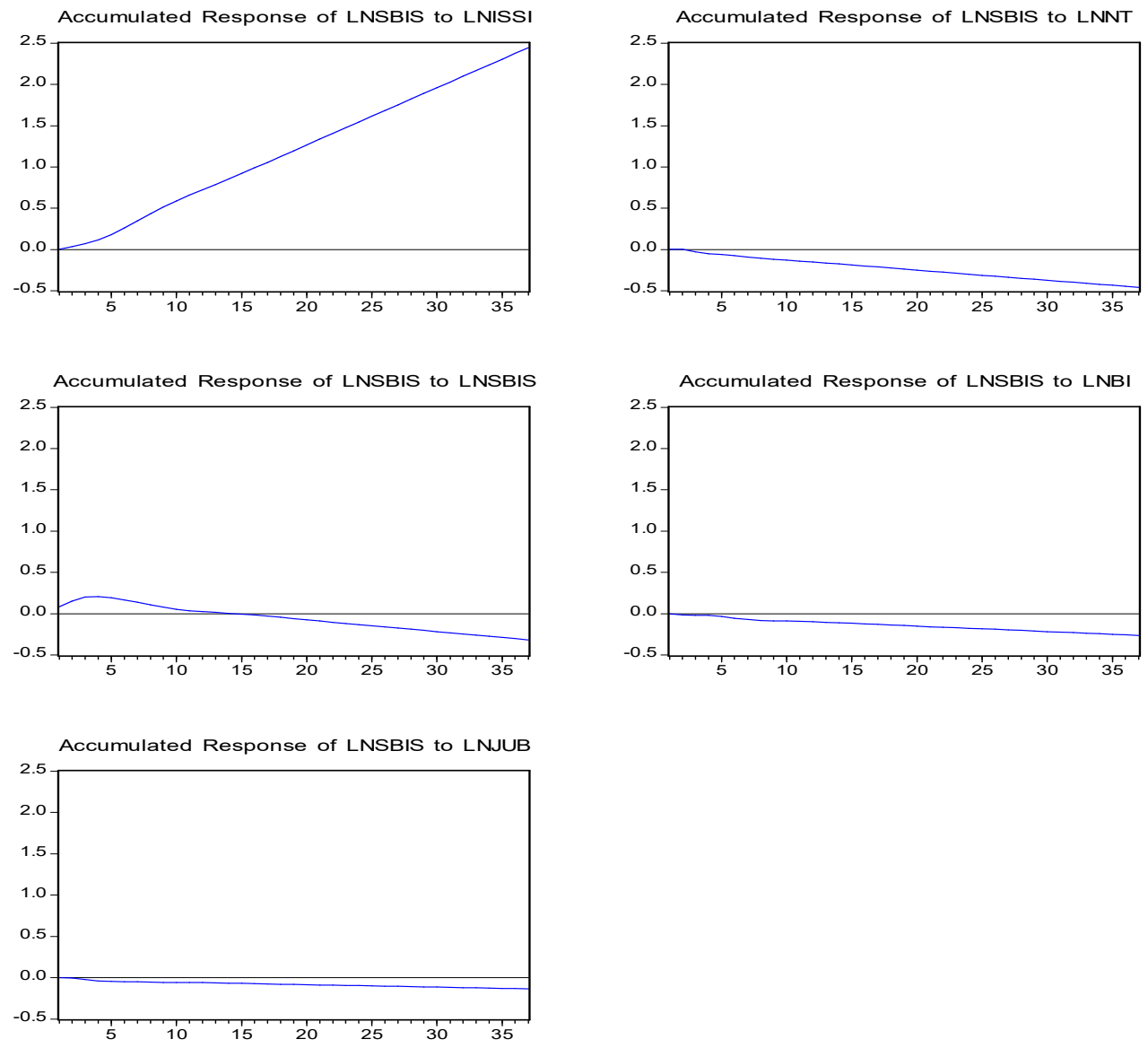

Sumber: BI dan OJK, data diolah, 2019

\section{Gambar 4. Respon Variabel Sertifikat Bank Indonesia Syariah (SBIS) terhadap Kejutan Variabel lain dan Sendiri}

\section{Respon Variabel BI Rate (BI) terhadap Kejutan Variabel Lain dan Kejutannya Sendiri}

Variabel BI Rate (BI) memberi respon negative rata-rata sebesar -0,504\% terhadap kejutan Variabel Indeks Saham Syariah Indonesia (ISSI). Arti dari impulse response ini adalah bahwa setiap kejutan Variabel Indeks Saham Syariah Indonesia (ISSI) sebesar satu standar deviasi, maka akan mendorong menurunnya variabel BI Rate (BI) rata-rata sebesar -0,504\%. Variabel BI Rate (BI) memberi respon positif dengan nilai rata-rata sebesar $0,638 \%$ terhadap kejutan variabel Nilai Tukar (NT). Hasil ini 
menunjukkan bahwa setiap kejutan Variabel Nilai Tukar (NT) sebesar satu standar deviasi, maka mendorong meningkatnya variabel BI Rate (BI) rata-rata sebesar $0,638 \%$.

Kumulatif impulse response variabel BI Rate (BI) terhadap kejutan dari Variabel Sertifikat Bank Indonesia Syariah (SBIS). Variabel BI Rate (BI) memberi respon positif rata-rata sebesar 0,185\% terhadap kejutan variabel Sertifikat Bank Indonesia Syariah (SBIS). Hasil ini berarti bahwa setiap kejutan variabel Sertifikat Bank Indonesia Syariah (SBIS) sebesar satu standar deviasi, maka mendorong meningkatnya BI Rate (BI) rata-rata sebesar 0,185\%.

Kejutan variabel Jumlah Uang Beredar (JUB) diberi respon positif oleh variabel BI Rate (BI) rata-rata sebesar 0,114\%. Nilai ini menunjukkan bahwa setiap kejutan variabel Jumlah Uang Beredar (JUB) sebesar satu standar deviasi, maka mendorong meningkatnya BI Rate (BI) rata-rata sebesar 0,114\%. Variabel BI Rate (BI) memberi respon positif rata-rata sebesar 1, 27\% terhadap kejutan dari variabel BI Rate (BI) itu sendiri. Hasil ini menunjukkan bahwa setiap kejutan BI Rate (BI) sebesar satu standar deviasi, maka akan mendorong meningkatnya BI Rate (BI) rata-rata sebesar 1,27\%. Nilai ratarata respon ini termasuk nilai yang tertinggi, sehingga bisa disimpulkan bahwa BI Rate (BI) lebih merespon pada perubahan nilai BI Rate (BI) sendiri daripada variabel lain.
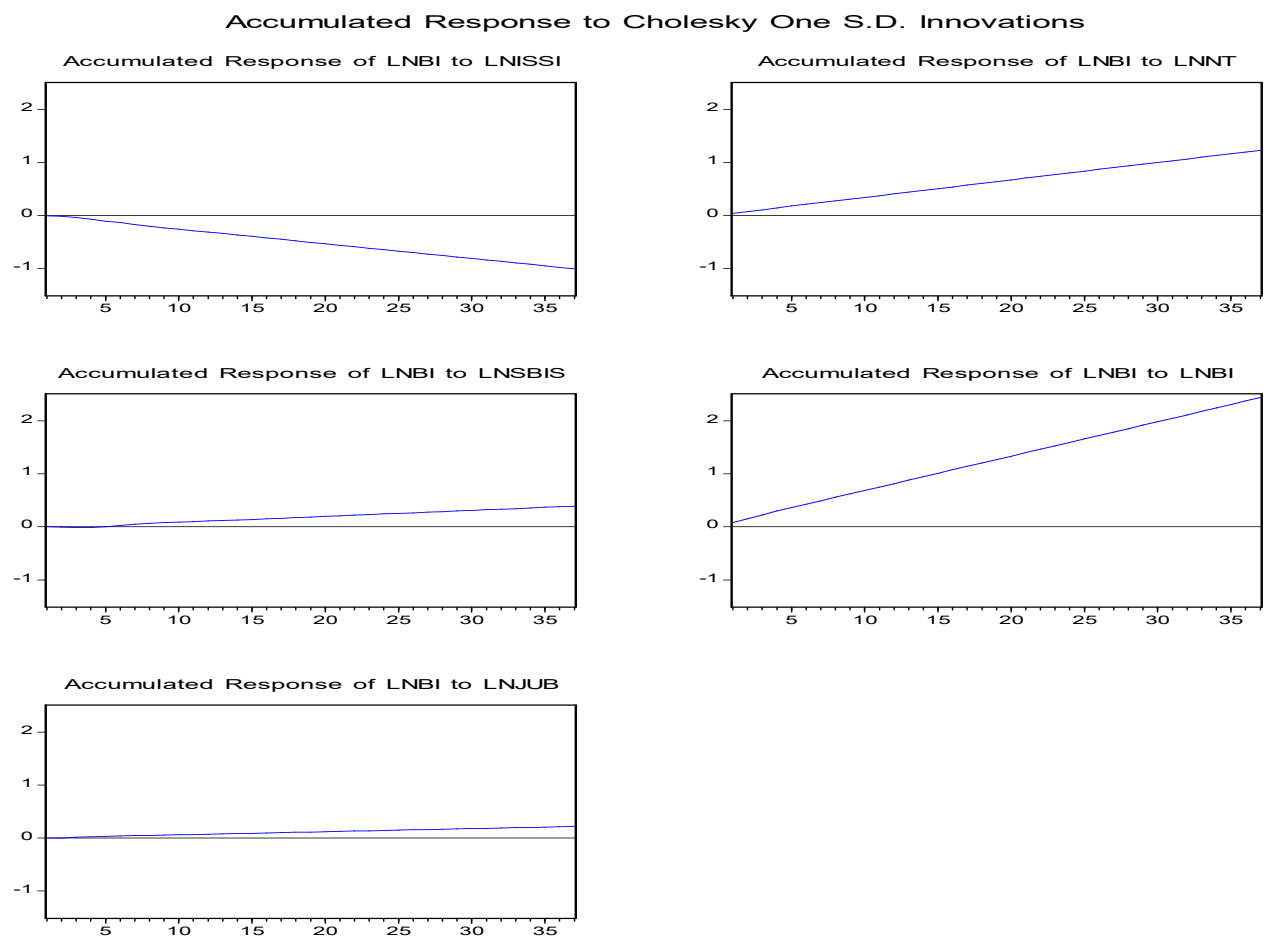

Sumber: BI dan OJK, data diolah, 2019

\section{Gambar 5. Respon Variabel BI Rate (BI) terhadap Kejutan Variabel lain dan Sendiri}

\section{Respon Variabel Jumlah Uang Beredar (JUB) terhadap Kejutan Variabel lain dan Kejutannya Sendiri}

Variabel Jumlah Uang Beredar (JUB) memberi respon positif rata-rata sebesar 0,009\% terhadap kejutan variabel Indeks Saham Syariah Indonesia (ISSI). Hasil ini berarti bahwa setiap kejutan Variabel Indeks Saham Syariah Indonesia (ISSI) sebesar satu standar deviasi, maka mendorong meningkatkan Jumlah Uang Beredar (JUB) rata-rata sebesar 0,009\%. Respon variabel Jumlah Uang Beredar (JUB) terhadap 
kejutan variabel Nilai Tukar (NT) adalah positif rata-rata sebesar $0,038 \%$. Nilai rata-rata ini berarti bahwa setiap kejutan Nilai Tukar (NT) sebesar satu standar deviasi, maka akan mendorong meningkatkan variabel Jumlah Uang Beredar (JUB) rata-rata sebesar 0,038\%.

Kejutan dari variabel Sertifikat Bank Indonesia Syariah (SBIS) mendapatkan respon negative dari variabel Jumlah Uang Beredar (JUB). Respon negative tersebut rata-rata sebesar -0,093\%. Angka ini berarti bahwa setiap kejutan Variabel Sertifikat Bank Indonesia Syariah (SBIS) sebesar satu standar deviasi, maka mendorong menurunnya Jumlah Uang Beredar (JUB) rata-rata sebesar -0,093\%. Variabel Jumlah Uang Beredar (JUB) juga memberi respon negative terhadap kejutan Variabel BI Rate (BI). Respon negative tersebut rata-rata sebesar -0,011\%. Hasil ini menunjukkan bahwa setiap kejutan BI Rate (BI) sebesar satu standar deviasi, maka akan mendorong menurunnya Jumlah Uang Beredar (JUB) rata-rata sebesar $-0,011 \%$.

Jumlah Uang Beredar (JUB) memberi respon positif rata-rata sebesar 0,072\% terhadap kejutan variabel Jumlah Uang Beredar (JUB) itu sendiri. Nilai tersebut menunjukkan bahwa setiap kejutan variabel Jumlah Uang Beredar (JUB) sebesar satu standar deviasi, maka mendorong meningkatnya Jumlah Uang Beredar (JUB) rata-rata sebesar 0,072\%.
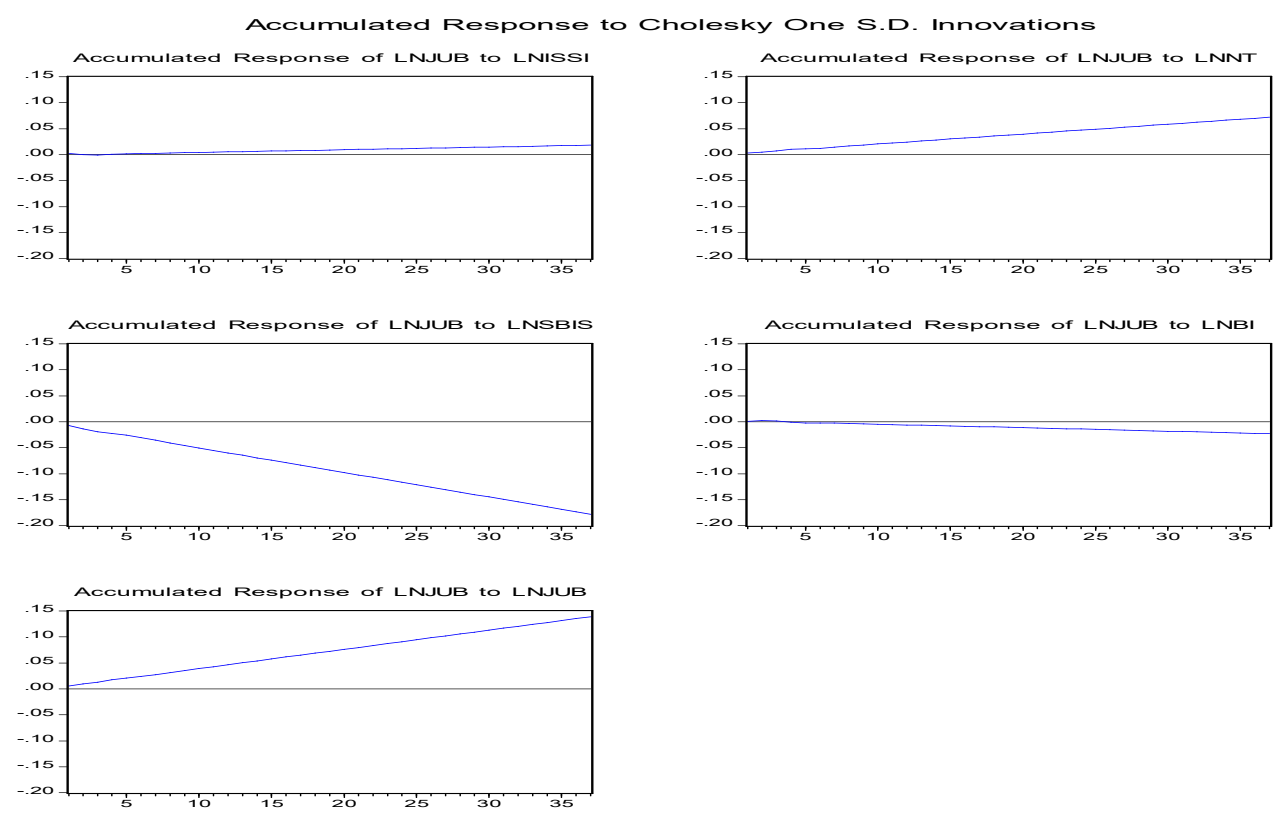

Sumber: BI dan OJK, data diolah, 2019

\section{Gambar 6. Respon Variabel Jumlah Uang Beredar (JUB) terhadap Kejutan Variabel lain dan Kejutannya Sendiri}

\section{DISKUSI}

Kontribusi Nilai Tukar (NT) terhadap pergerakan Indeks Saham Syariah Indonesia (ISSI) terlihat dari nilai Variance Decomposition. Nilai Tukar (NT) hanya memberi kontribusi sebesar 0,558\% terhadap pergerakan Indeks Saham Syariah Indonesia (ISSI). Sementara Indeks Saham Syariah Indonesia memberi kontribusi terhadap pergerakan Nilai Tukar sebesar 22,178\%. Hasil ini menunjukkan bahwa pengaruh Nilai Tukar (NT) terhadap pergerakan Indeks Saham Syariah Indonesia (ISSI) selama 37 
bulan periode Januari 2016-Januari 2019 lebih kecil dibanding dengan pengaruh Indeks Saham Syariah Indonesia (ISSI) terhadap pergerakan Nilai Tukar (NT). Hasil penelitian ini sesuai dengan penelitian yang dilakukan oleh Ardana (2016), Tesa (2012), Rachmawati dan Laila (2015), Sudarsono (2018), Suciningtias dan Khoiroh (2015). Penelitian ini menghasilkan bahwa ada pengaruh negative Nilai Tukar (NT) terhadap pergerakan Indeks Saham Syariah Indonesia (ISSI).

Kontribusi Sertifikat Bank Indonesia Syariah (SBIS) terhadap pergerakan Indeks Saham Syariah Indonesia (ISSI) terlihat dari nilai Variance Decomposition. Sertifikat Bank Indonesia Syariah (SBIS) hanya memberi kontribusi sebesar 18, 93\% terhadap pergerakan Indeks Saham Syariah Indonesia (ISSI). Sementara Indeks Saham Syariah Indonesia memberi kontribusi terhadap pergerakan Sertifikat Bank Indonesia Syariah (SBIS) sebesar 66, 52\%. Hasil ini menunjukkan bahwa pengaruh Sertifikat Bank Indonesia Syariah (SBIS) terhadap pergerakan Indeks Saham Syariah Indonesia (ISSI) selama 37 bulan periode Januari 2016-Januari 2019 lebih kecil dibanding dengan pengaruh Indeks Saham Syariah Indonesia (ISSI) terhadap pergerakan Sertifikat Bank Indonesia Syariah (SBIS). Hasil penelitian ini berbeda dengan penelitian yang dilakukan oleh Suciningtias dan Khoiroh (2015). Hasil penelitian Suciningtias dan Khoiroh (2015) adalah bahwa ada pengaruh yang tidak signifikan antara variabel SBIS terhadap variabel ISSI. Sementara hasil penelitian ini menunjukkan bahwa ada pengaruh Sertifikat Bank Indonesia Syariah (SBIS) terhadap pergerakan Indeks Saham Syariah Indonesia (ISSI) secara signifikan.

Kontribusi BI Rate (BI) terhadap pergerakan Indeks Saham Syariah Indonesia (ISSI) terlihat dari nilai Variance Decomposition. BI Rate (BI) memberi kontribusi sebesar 9,799\% terhadap pergerakan Indeks Saham Syariah Indonesia (ISSI). Sementara Indeks Saham Syariah Indonesia memberi kontribusi terhadap pergerakan BI Rate (BI) sebesar 10, 38\%. Hasil ini menunjukkan bahwa pengaruh BI Rate (BI) terhadap pergerakan Indeks Saham Syariah Indonesia (ISSI) selama 37 bulan periode Januari 2016-Januari 2019 lebih kecil dibanding dengan pengaruh Indeks Saham Syariah Indonesia (ISSI) terhadap pergerakan BI Rate (BI). Hasil penelitian ini sesuai dengan penelitian yang dilakukan oleh Sudarsono (2018), namun berbeda dengan hasil penelitian Rachmati dan Laila (2015). Hasil penelitian Sudarsono (2018) menunjukkan adanya pengaruh antara tingkat BI Rate dengan ISSI, sementara hasil penelitian Rachmawati dan Laila (2015) menunjukkan hasil pengaruh yang tidak signifikan.

Kontribusi Penawaran Uang (M2)/Jumlah Uang Beredar (JUB) terhadap pergerakan Indeks Saham Syariah Indonesia (ISSI) terlihat dari nilai V ariance Decomposition. Penawaran Uang (M2)/Jumlah Uang Beredar (JUB) memberi kontribusi sebesar 1,349\% terhadap pergerakan Indeks Saham Syariah Indonesia (ISSI). Sementara Indeks Saham Syariah Indonesia memberi kontribusi terhadap pergerakan Penawaran Uang (M2)/Jumlah Uang Beredar (JUB) sebesar 2,764\%. Hasil ini menunjukkan bahwa pengaruh Penawaran Uang (M2)/Jumlah Uang Beredar (JUB) terhadap pergerakan Indeks Saham Syariah Indonesia (ISSI) selama 37 bulan periode Januari 2016-Januari 2019 lebih kecil dibanding dengan pengaruh Indeks Saham Syariah Indonesia (ISSI) terhadap pergerakan Penawaran Uang (M2)/Jumlah Uang Beredar (JUB). Hasil penelitian ini sesuai dengan penelitian yang dilakukan oleh Sudarsono (2018), Hasil penelitian Sudarsono (2018) menunjukkan adanya pengaruh antara tingkat Penawaran Uang (M2)/Jumlah Uang Beredar (JUB) dengan ISSI.

\section{SIMPULAN}

Berdasarkan hasil penelitian dapat disimpulkan Nilai Tukar berpengaruh terhadap pergerakan Indeks Saham Syariah Indonesia (ISSI). Nilai Tukar berpengaruh mendorong menurunnya Indeks Saham 
Syariah Indonesia (ISSI). Namun kontribusi Nilai Tukar terhadap Indeks Saham Syariah Indonesia (ISSI) paling kecil dibandingkan dengan variabel lain. Sertifikat Bank Indonesia Syariah (SBIS) berpengaruh terhadap pergerakan Indeks Saham Syariah Indonesia (ISSI).

Sertifikat Bank Indonesia Syariah (SBIS) berpengaruh mendorong menurunnya Indeks Saham Syariah Indonesia (ISSI). Kontribusi Sertifikat Bank Indonesia Syariah (SBIS) cukup besar yaitu ratarata sebesar 18,93\% selama 37 bulan periode Januari 2016-Januari 2019. Bank Indonesia Rate (BI) berpengaruh terhadap pergerakan Indeks Saham Syariah Indonesia (ISSI). BI Rate (BI) berpengaruh mendorong meningkatnya Indeks Saham Syariah Indonesia (ISSI). Kontribusi rata-rata BI Rate (BI) terhadap Indeks Saham Syariah Indonesia cukup besar yaitu 9,799\%. Penawaran Uang (M2)/Jumlah Uang Beredar (JUB) berpengaruh terhadap pergerakan Indeks Saham Syariah Indonesia (ISSI). Penawaran Uang (M2)/Jumlah Uang Beredar (JUB) berpengaruh mendorong meningkatnya Indeks Saham Syariah Indonesia (ISSI). Kontribusi rata-rata Penawaran Uang (M2)/Jumlah Uang Beredar (JUB) tidak terlalu besar hanya sebesar 1,349\%.

Variabel Nilai Tukar dan Variabel Sertifikat Bank Indonesia Syariah (SBIS) memiliki nilai pengaruh negatif terhadap Indeks Saham Syariah Indonesia (ISSI). Namun kontribusi variabel SBIS lebih besar dari Nilai Tukar terhadap ISSI. Hal ini menunjukkan bahwa variabel Nilai Tukar (NT) kurang tepat dapat melihat faktor yang mempengaruhi pergerakan Indeks Saham Syariah Indonesia (ISSI).

\section{Saran}

Hasil penelitian ini menunjukkan bahwa variabel Nilai Tukar dan Sertifikat Bank Indonesia Syariah (SBIS) mendorong terjadinya penurunan Indeks Saham Syariah Indonesia (ISSI), sehingga dua variabel tersebut menjadi perhatian bagi pengambil kebijakan dalam menentukan harga saham di Indeks Saham Syariah Indonesia (ISSI)

\section{Keterbatasan dan Penelitian Berikutnya}

Semua data dalam penelitian ini menjadi stasioner pada saat diferensi pertama. Hal ini menunjukkan adanya kekurangan data sehingga tidak terlihat stasioner ketika dilakukan uji stasioner. Guna penelitian lebih lanjut maka sebenarnya dapat ditambahkan variabel sukuk yang juga merupakan instrumen keuangan syariah.

\section{Ucapan Terima Kasih}

Terimakasih pada Otoritas Jasa Keuangan dan Bank Indonesia atas kontribusi datanya

\section{REFERENSI}

Ardana, Yudhistira. (2016). Pengaruh Variabel Makroekonomi Terhadap Indeks Saham Syariah Di Indonesia: Model ECM. Esensi: Jurnal Bisnis dan Manajemen. Volume 6 (1), pp. 17-28

Asmy, M., Rohilina, W., Hassama, A., \& Fouad, M (2010). Effects of Macroeconomic Variables on Stock Prices in Malaysia: An Approach of Error Correction Model. MPR A Paper. No. 20970

Bekhet, H. A. \& Mugableh, M. I. (2012). Investigating Equilibrium Relationship between Macroeconomic Variables and Malaysian Stock Market Index through Bounds Tests Approach. International Journal of Economics and Finance. Vol. 4(10): 69-81

Ferdinand. (2002). Metode Penelitian Manajemen : Pedoman penelitian untuk Skripsi, Tesis, dan Desertasi Imu Manajemen, Semarang : Badan Penerbit Universitas Diponegoro.

Hermuningsih, Sri, Hanita Yuniati, Mujino, (2017) Apakah Indeks Saham Syariah Indonesia (Issi) Memediasi Pengaruh Nilai Tukar Terhadap Return Saham Syariah, Jurnal Manajemen dan Bisnis Indonesia, Vol 4 (2) : 185-199 
Hosseini, S. M., Ahmad, Z., \& Lay, Y. W. (2011). The Role of Macroeconomic Variables on Stock Market Index in China and India. International Journal of Economics and Finance. Vol. 3(6): 233-243

Huda, Nurul, Mustafa Edwin Nasution (2014), Investasi Pada Pasar Modal Syariah, cetakan ketiga, Prenada Kencana

Hussin, M. Y. M., Muhammad, F., Abu, M. F. \& Awang, S.A. (2012). Macroeconomic Variable and Malaysian Islamic Stock Market: A time Series Analysis. Journal of Business Studies Quarterly. Vol. 3 (4): 1-13.

Kholidah, Nur., Miftahur Rahman Hakim (2019) melakukan penelitian dengan judul “Analisis Kinerja Reksadana Saham Syariah Dengan Metode Sharpe, Treynor, Jensen, $\mathrm{M}^{2}$, Dan TT, Indonesian Interdisciplinary Journal of Sharia Economics (IIJSE) Vol. 1(2) : 29-40

Majid, M. S. A., \& Yusof, R. M.( 2009). Long-run Relationship Between Islamic Stock Returns and Macroeconomic Variables An Application of The Autoregressive Distributed Lag Model. Humanomics. Vol. 25 (2): 127-141.

Menike, L. M. C. S. (2006). The Effect of Macroeconomic Variables on Stock Prices in Emerging Sri Lanka Stock Market. Sabaragamuwa University Journal. Vol. 6 (1): 50-67

Pasaribu, R. B. F \& Firdaus, M. (2013). Analisis Pengaruh Variabel Makroekonomi terhadap Indeks Saham Syariah Indonesia. Jurnal Ekonomi \& Bisnis. Vol. 7(2): 117-128

Rachmawati, Martien., Laila, Nisful. (2015). Faktor Makroekonomi Yang Mempengaruhi Pergerakan Harga Saham Pada Indeks Saham Syariah Indonesia (ISSI) Di Bursa Efek Indonesia (BEI). JESTT Vol. 2 No. 11. Pp. 928-942

Sakinah, Rachman dan Sri Herianingrum (2018) "Pengaruh Instrumen Sertifikat Bank Indonesia (SBI), Pasar Uang Antar Bank (PUAB), Sertifikat Bank Indonesia Syariah (SBIS), Pasar Uang Antar Bank Syariah (PUAS) Terhadap M2 Di Indonesia Periode 2009-2016, Jurnal Ekonomi Syariah Teori dan Terapan Vol. 5 (1): 79-92

Saputra, Rega, Erdah Listriani dan Dinnul Alfian Akbar (2017), Pengaruh Bi Rate, Inflasi, Nilai Tukar Rupiah, Dan Sertifikat Bank Indonesia Syariah (SBIS) Terhadap Indeks Saham Syariah Indonesia (ISSI), I-Economic Vol.3(1): 51-72

Suciningtias, S.A. \& R. Khoiroh. (2015). Analisis Dampak Variabel Makroekonomi terhadap Indeks Saham Syariah Indonesia (ISS). Jurnal CBAM Unissula. Vol 2 No.1, hlm. 399-412.

Sudarsono, Heri. (2018). Indikator Makroekonomi dan Pengaruhnya Terhadap Indeks Saham Syariah Indonesia. Esensi: Jurnal Bisnis dan Manajemen Volume 8 (2), pp. 115-132

Tesa, Silvia. 2012. Pengaruh Suku Bunga Internasional, Nilai Tukar Rupiah /U\$ Dan Inflasi Terhadap Indeks Harga Saham Gabungan Di Bursa Efek Gabungan Tahun 2000-2010. Economics Development Analysis Journal, 1(1), pp:1-13

Widowati, Nuzulia Dwi. (2018). Analisis Integrasi Indeks Saham Syariah Dunia dan Kinerja Variabel Makroekonomi Terhadap ISSI. Tesis. Universitas Islam Indonesia. Yogyakarta 